\title{
GPS DEFORMATION MONITORING OF THE TETON FAUlt, Grand TETON NATIONAL PARK AND SURROUNDING AREA, WYOMING, FOR 2010
}

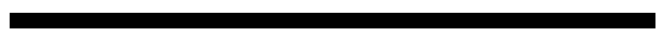

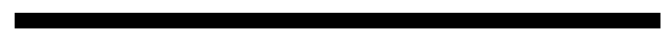

\section{$\uparrow \quad$ INTRODUCTION}

Recent earthquake activity in the Jackson Hole area, particularly the 2010 Gros Ventre sequence, has focused on possible regional ground deformation that may be related to the earthquakes (Farrell et al., 2010). The University of Utah has an established network of field GPS benchmarks that was last surveyed in 2003 and has now been resurveyed in 2010 (Figure 1). The campaign GPS measurements supplement the permanent regional GPS network and provide detailed information on temporal and spatial deformation in and around Grand Teton National Park.
\end{abstract}

\section{Christine M. PUSKAS $\downarrow$ ROBERT B. SMITH $\downarrow$ WU-LUNG CHAN UNIVERSITY OF UTAH $\downarrow$ SALT LAKE}

The Teton fault is a large and active normal fault bounding the Teton Range in Grand Teton National Park. The fault has had no moderate or large earthquakes $(M>4)$ in historic time (Byrd et al., 1994) but is surrounded by a diffuse pattern of earthquake epicenters in the southern Teton Range and in the Gros Ventre Range. The Teton fault is capable of producing significant, M6+ earthquakes and is one of the most hazardous Late Quaternary faults in the Intermountain region (White et al., 2009). The seismic hazard arises from the expected ground acceleration during a large earthquake and is related to fault loading rate, i.e., the rate at which the crust is extending across a fault. This stretching rate can be assessed by GPS measurements.

The diffuse seismicity around the Teton fault zone indicates that deformation is generally not concentrated along the Teton fault. Teton fault deformation has previously been studied through campaign GPS measurements (Puskas et al., 2007), precise leveling of benchmarks (Sylvester et al., 2001), and fault scarp offset measurements (Byrd, 1995). The GPS and leveling studies discovered an unexpected deformation signal of the Jackson Hole area: uplift of the valley floor relative to the mountains. The GPS measurements also revealed minor contraction of $0.34 \pm 0.06$ across the fault, contrary the standard pattern of extension across a normal fault (Figure 2). The University of Utah has previously conducted GPS campaigns in 1987, 1989, 1991, 1993, 1995, 2000, and 2003.

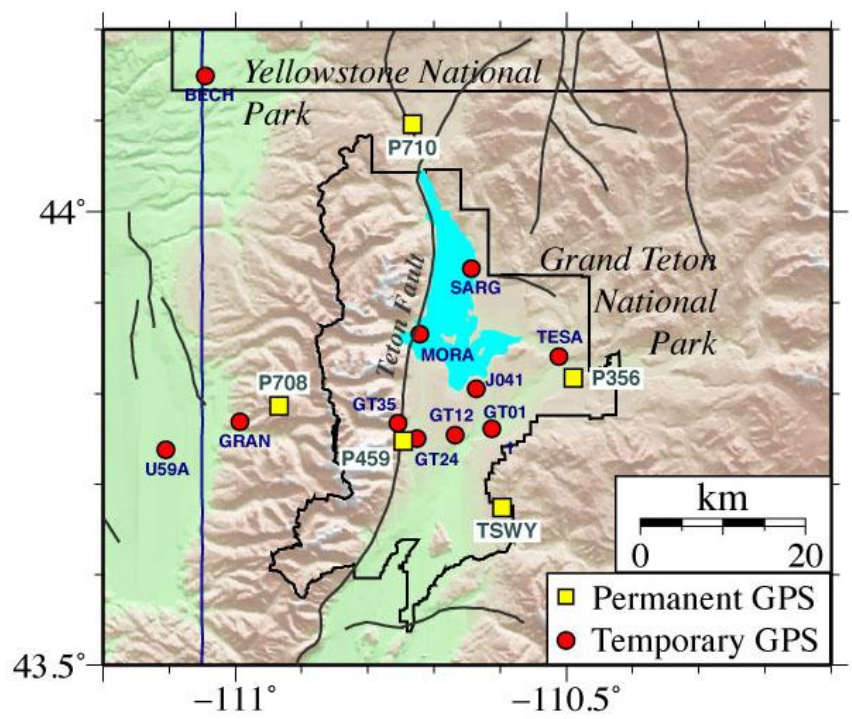

Figure 1. Campaign (red) and permanent (GPS) stations in and around Grand Teton National Park. Only campaign GPS sites occupied in 2010 are shown. 
University of Utah field crews visited 11 of our GPS benchmarks in and around Grand Teton National Park over a period of 5 days. A portable GPS receiver and antenna was set up at each site and operated for 1-3 days. GPS receivers recorded data at a 30 -second sampling interval.

The GPS data are being processed using the Bernese 4.2 software, employing differential GPS techniques. The results provide station position solutions for each day of observation (Puskas et al., 2010). The station positions from the 2010 campaign will then be combined with the positions from prior campaigns to evaluate the change in position over time, i.e. ground velocity ( $\mathrm{mm} / \mathrm{yr})$. Because GPS campaigns are done every few years, they yield information on the net change in positions. Permanent GPS stations, because they operate continuously and thus have positions for every day, provide information on short-term changes in position. However, permanent GPS stations are much more expensive to operate and maintain, so are much fewer in number compared to the campaign stations. For our 2010 study, we will incorporate both the campaign and permanent GPS station data.

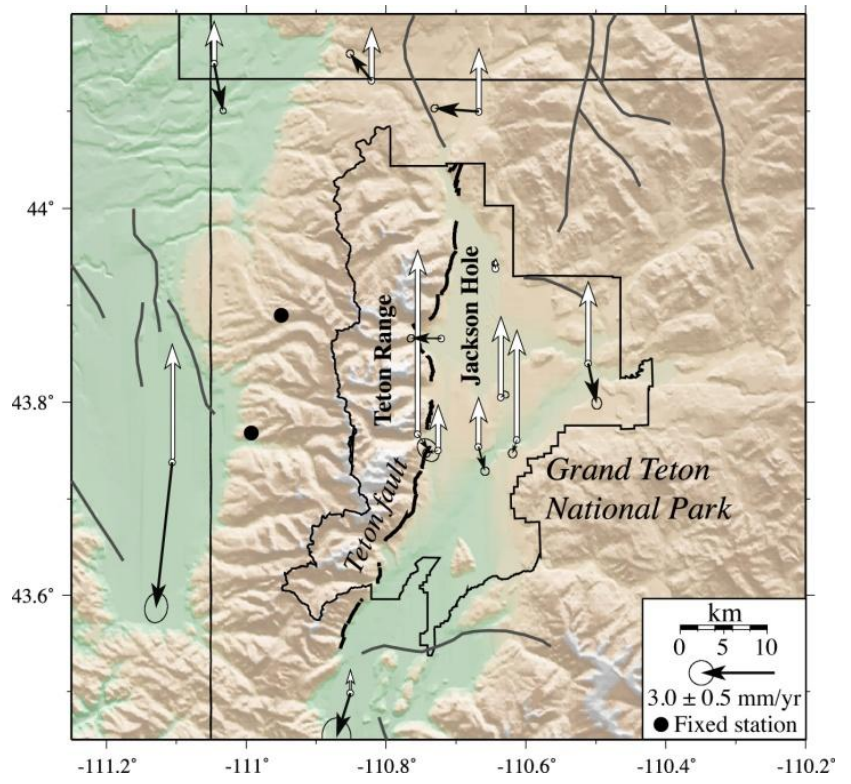

Figure 2. 1987-2003 deformation of the Teton region. Black arrows represent horizontal motion; white arrows represent vertical motion. Deformation is relative to the Teton Range, i.e., the mountains are set to have zero motion.
Information about current University of Utah research on the Teton fault and Yellowstone volcanic field can be obtained at http://www.uusatrg.utah.edu.

\section{$\uparrow \quad$ Literature Cited}

Byrd JOD, Smith RB, Geissman JW. 1994. The Teton Fault, Wyoming: Topographic signature, neotectonics and mechanisms of deformation, J. Geophys. Res. 99, 20,09520,122 .

Byrd JOD. 1995. Neotectonics of the Teton fault, Wyoming, Ph.D. dissertation, 214 pp, Univ. of Utah, Salt Lake City.

Farrell JM, Smith R, Massin F, White B. 2010. Persistent seismicity and energetics of the 2010 earthquake sequence of the GrosVentre-Teton area, Wyoming, Abstract T51C-2073 presented at 2010 Fall Meeting, AGU, San Francisco, Calif., 13-17 Dec.

Puskas C, Smith RB, Chang WL, Farrell J. 2010. GPS research and monitoring of the Yellowstone volcanic system, WY-ID-MT, and the Wasatch fault, UT: A White Paper, University of Utah Seismology and Active Tectonics Research Group, Department of Geology and Geophysics, University of Utah, 46pp.

Puskas CM, Smith RB, Meertens CM, Chang WL. 2007. Crustal deformation of the Yellowstone-Snake River Plain volcanic system: campaign and continuous GPS observations, 1987-2004. J. Geophys. Res. 112, B03401, doi:10.1029/2006JB004325.

Sylvester AG, Smith RB, Chang W, Hitchcock CS, Byrd JO. 2001. First-order leveling and campaign GPS reveal anomalous, interseismic, contractile, transient strain across Teton normal fault, 1988- 2001, Eos Trans. AGU, 82(47). Fall Meet. Suppl., Abstract G22D-04.

White BJP, Smith RB, Husen S, Farrell J, Wong I. 2009. Seismicity and earthquake hazard analysis of the Teton-Yellowstone region, Wyoming, J. Vol. Geotherm. Res. 188, 277296, doi:10.1016/j.jvolgeores .2009.08. 